\title{
Helper Component Mutations in Nonconserved Residues Associated with Aphid Transmission Efficiency of a Pepper Isolate of Potato Virus Y
}

\author{
César Llave, Belén Martínez, J. R. Díaz-Ruíz, and D. López-Abella
}

Departamento de Biología de Plantas, Centro de Investigaciones Biológicas, C.S.I.C., Velázquez 144, 28006 Madrid, Spain. Accepted for publication 16 August 1999.

\begin{abstract}
Llave, C., Martínez, B., Díaz-Ruíz, J. R., and López-Abella, D. 1999. Helper component mutations in nonconserved residues associated with the aphid transmission efficiency of a pepper isolate of potato virus Y. Phytopathology 89:1176-1181.

The aphid transmission properties of a pepper isolate of potato virus $\mathrm{Y}$ belonging to the pathotype 1-2 (PVY 1-2) have been characterized. PVY 1-2 was not transmitted in plant-to-plant experiments, although purified virus particles were efficiently transmitted when supplemented with heterologous helper component (HC) of the transmissible isolate PVY 0 AT through membrane acquisition assays, indicating that its coat protein

was functional in transmission. Additionally, virions of PVY 1-2 were able to bind to different HCs in in vitro binding assays. Analysis of the sequence of the PVY 1-2 HC gene and comparison with that of PVY 0 AT revealed 19 nucleotide differences, but only 2 resulted in amino acid changes, one of which induced a change of charge. Neither of these two amino acid changes occurred within the cysteine-rich domain, nor did they coincide with conserved motifs of the HC protein known to be involved in aphid transmission and which are present in all known potyviruses. However, both changes are located in positions highly conserved among PVY strains. The possible role of both mutations on the activity of the PVY 1-2 HC in aphid transmission is discussed.
\end{abstract}

Potato virus Y (PVY) is the type member of the genus Potyvirus (family Potyviridae), the largest group of RNA plant viruses (17, 18). PVY consists of a complex group of strains and pathotypes which have been identified and classified according to their biological properties and that cause serious losses in many important crops all over the world, including pepper (9). PVY isolates infecting pepper (Capsicum annuum L.) have been classified into three pathotypes (types 0,1 , and 1-2) based on their ability to overcome certain resistance genes of pepper to PVY infection (12).

Nonpersistent aphid transmission of potyviruses requires, in addition to virions, a virus encoded non-structural protein, "helper component" (HC), which is essential for virion retention in the stylets of the aphid (2,33). This protein has been speculated to act as a bridge between the coat protein $(\mathrm{CP})$ of the virus particle and a putative receptor in the aphid mouthparts (23). A number of potyvirus strains which are naturally nontransmissible by aphids due to alterations in the amino acid sequence of the $\mathrm{HC}$ have been reported $(8,13,20,30)$. In addition, mutational analysis has proved that two highly conserved motifs in the HC sequence are directly involved in the activity of this protein during the transmission process. Substitution of Lys to Glu or to other amino acids besides Arg in the highly conserved Lys-Ile-Thr-Cys (KITC) sequence at the N-terminus of the $\mathrm{HC}$ of tobacco vein mottling virus (TVMV; 3,4 ) and Lys to Glu in the KITC box of tobacco etch virus (TEV; 5) resulted in loss of $\mathrm{HC}$ activity. The KITC box, which lies in a conserved cysteine-rich region, has been suggested to be required for the interaction of $\mathrm{HC}$ with aphid stylets (5). Certain mutations in the conserved Pro-Thr-Lys (PTK) motif at the central region of the $\mathrm{HC}$ of zucchini yellow mosaic virus (ZYMV) recently have been shown to result in loss of aphid transmission and virion-HC

Corresponding author: D. López-Abella; E-mail address: dlabella@ cib.csic.es

The nucleotide sequence data reported in this article was submitted to GenBank and assigned accession no. AF 166115.

Publication no. P-1999-1018-02R

(C) 1999 The American Phytopathological Society binding (21). Additionally, a Phe to Leu replacement at amino acid 10 of the HC of TEV also renders HC nonfunctional (5). The knowledge of the domains or amino acid residues involved in the activity of the $\mathrm{HC}$ during the transmission process might facilitate the design of new disease control strategies for preventing virus spread by aphids in nature.

We have previously characterized the aphid transmission properties of pepper pathotypes PVY 0 and PVY 1 (8). In the present work, we analyzed the aphid transmission properties of a PVY isolate belonging to pepper pathotype 1-2 and determined the complete nucleotide and predicted amino acid sequence of its $\mathrm{HC}$.

\section{MATERIALS AND METHODS}

Virus isolates. The isolate P-22-88, belonging to the PVY pepper pathotype 1-2 and originating from Spanish field-grown pepper plants, was used in this study. This isolate was classified and provided by M. P. Luis-Arteaga (SIA-DGA, Zaragoza, Spain) and was maintained in C. annuum L. 'Yolo Y,' Nicotiana tabacum L. 'Xanthi nc,' and N. sylvestris through repeated mechanical passages. P-22-88 was designated here, for simplicity, as PVY 1-2. The aphid-transmissible isolate PVY 0 AT and the non-aphid transmissible isolate PVY 1 were used in previous studies (8).

Purified virus and HC preparation. Viruses and HCs were purified from leaves of systemically infected tobacco plants 3 weeks after inoculation and assayed for biological activity as described $(19,24)$. Virus concentrations were determined spectrophotometrically and $\mathrm{HC}$ preparations were analyzed by sodium dodecyl sulfate-polyacrylamide gel electrophoresis (SDS-PAGE) on 10\% polyacrylamide gels and electroblotted onto nitrocellulose following the method of Towbin et al. (31). PVY HC monoclonal antibodies (MAbs) were used for $\mathrm{HC}$ immunodetection (7). HC preparations were shown to be virus-free (data not shown) by membrane acquisition tests (described below) and mechanical inoculation on tobacco plants.

Aphid transmission assays. The procedures for rearing and handling the aphids (Myzus persicae Sulzer) as well as the transmission assays, either by in vivo acquisition from plants or in 
vitro through Parafilm membranes, have been described elsewhere (22). Acquisition access feeding was for 5 to $10 \mathrm{~min}$, and inoculation access feeding was overnight. Aphids were killed by spraying with an insecticide, and the plants were placed in a growth room. Plant infection was confirmed after 2 or 3 weeks by doubleantibody sandwich enzyme-linked immunosorbent assay (DASELISA) using MAbs to PVY (Ingenasa, Madrid). Purified viruses and partially purified HCs from PVY 1-2 and PVY 0 AT used in membrane transmission tests were adjusted to equal concentrations by western blot analysis to compare the level of aphid transmission of both isolates.

Dot-blot binding assay. The binding reaction between $\mathrm{HC}$ and PVY 1-2 virions was conducted according to Blanc et al. (5). Partially purified PVY 1-2 HC and PVY 0 AT HC were blotted on nitrocellulose membranes to be incubated with purified PVY 1-2 virions at a concentration of $3 \mu \mathrm{g} / \mathrm{ml}$. Blots were successively probed with a polyclonal anti-PVY virion antibody, with goat antirabbit peroxidase conjugate and chromogenic substrate. As a control, purified TEV HC (6) was also dot blotted on nitrocellulose membrane and processed as described above.

Cloning and sequencing of the PVY 1-2 HC gene. Amplification of the PVY 1-2 HC-encoding region was carried out by immunocapture (34) followed by two-step reverse-transcriptase polymerase chain reaction (RT-PCR; 8). Immunocapture of clarified PVY 1-2-infected tobacco extract was performed directly in the tubes used for the RT-PCR reactions, which were previously coated with PVY polyclonal antibodies. The following PCR amplification scheme was used: denaturation for $5 \mathrm{~min}$ at $92^{\circ} \mathrm{C} ; 25$ cycles of $30 \mathrm{~s}$ at $92^{\circ} \mathrm{C}, 1 \mathrm{~min}$ at $52^{\circ} \mathrm{C}$, and $1 \mathrm{~min}$ and $30 \mathrm{~s}$ at $72^{\circ} \mathrm{C}$; and a final 5-min elongation step at $72^{\circ} \mathrm{C}$. The downstream $\mathrm{HC} 1$ (5' ACCAACTCTATAGTGTTT 3') and upstream HC2 (5' CGTTCCAAAGTCACTC 3') oligonucleotide primers at positions 2404 and 992, respectively, were designed according to the genomic sequence of the PVY 0 and PVY N isolates $(8,26)$. Amplified cDNA fragments were purified from agarose gels using GeneClean (Bio 101, Vista, CA) and directly cloned into a PCR fragment cloning vector pGEM-T Easy (Promega Corp., Madison, WI). Recombinant plasmids were used to transform competent Escherichia coli DH5 $\alpha$. Positive clones were tested by restriction enzyme analysis of small-scale preparations of plasmid DNA. The nucleotide se-

TABLE 1. Efficiency of plant-to-plant transmission of pepper isolates of potato virus Y (PVY) pathotypes 1-2 and 0 by aphids

\begin{tabular}{lrrrrr}
\hline & \multicolumn{5}{c}{ Aphid transmission $^{\mathrm{a}}$} \\
\cline { 2 - 6 } Pathotype & Exp. 1 & Exp. 2 & Exp. 3 & Exp. 4 & \multicolumn{1}{c}{ Total } \\
\hline PVY 1-2 & $0 / 15$ & $0 / 15$ & $0 / 15$ & $0 / 15$ & $0 / 60$ \\
PVY 0 AT & $14 / 16$ & $14 / 18$ & $13 / 15$ & $15 / 15$ & $56 / 64$ \\
\hline
\end{tabular}

a Aphids (Myzus persicae) were starved for 2 to $3 \mathrm{~h}$ and allowed to feed for 5 to $10 \mathrm{~min}$ on virus-infected leaves. A total of 10 aphids per assay plant was used. Values are transmission frequencies based on number of infected plants/ total number of tested plants in each experiment. quence of the PVY 1-2 HC gene was obtained by means of an ABI PRISM sequencer (Applied Biosystems, Foster City, CA) with purified plasmids as templates. $\mathrm{HC} 1, \mathrm{HC} 2$ and the internal upstream HC3 primer (5' GCAAGCACCATTCAAG 3') were used for PVY 1-2 HC sequencing. Each nucleotide determination was performed on three independent clones and directly twice on cDNA obtained by RT-PCR from viral RNA. Nucleotide and amino acid sequences from PVY 1-2 and PVY 0 AT HCs were aligned and compared, using CLUSTAL W, version 1.5 (28), with the following PVY strains and potyviruses: PVY 0 AT, PVY 1 (8), PVY C (30), PVY H (V. Thole, T. Dalmay, J. Burgyan, and E. Balazs, unpublished data; GenBank accession no. M95491), PVY N (26), plum pox virus (PPV; 14), TEV (1), turnip mosaic virus (TuMV; 32), TVMV (10), and ZYMV (25).

\section{RESULTS}

Aphid transmission. In plant-to-plant experiments, transmission of PVY 1-2 was always negative regardless of the source of inocula (0\% of 60 assays), whereas PVY 0 AT was efficiently transmitted (87\% of 64 assays; Table 1). To determine whether the PVY 1-2 CP or HC were involved in this lack of transmissibility, a series of membrane acquisition transmission experiments were conducted with either homologous or heterologous combinations of purified virus and HC from PVY 0 AT and PVY 1-2.

Unlike the HC of PVY 1 (8), PVY 1-2 and PVY 0 AT HCs were readily partially purified from infected plants following standard procedures. Electrophoretic mobility, reactivity with PVY MAbs, and yield of purified HC were similar in PVY 1-2 and PVY 0 AT,

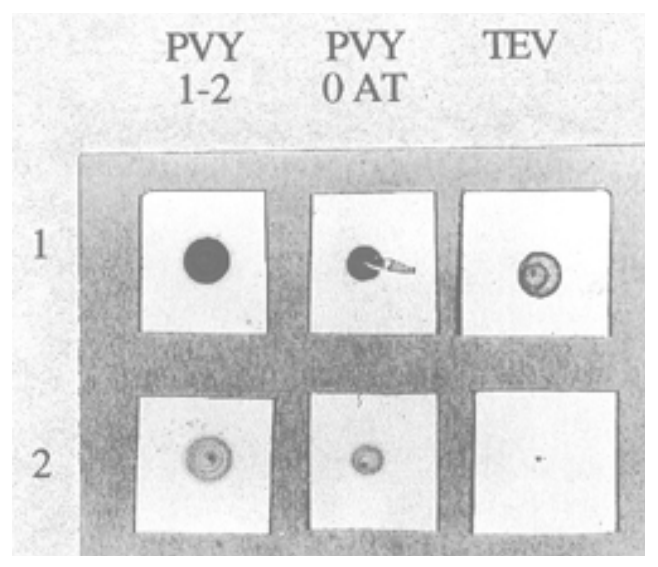

Fig. 1. Binding assay between different helper components (HCs) and virions of pepper isolate pathotype 1-2 of potato virus Y (PVY). Partially purified PVY 1-2 and PVY 0 AT HCs and purified tobacco etch virus (TEV) HC were dot-blotted on nitrocellulose. Blots were incubated with purified PVY 1-2 virions (panel 1) or buffer control (panel 2) and successively probed with antibodies to PVY virions, goat anti-rabbit peroxidase conjugate, and chromogenic substrate.

TABLE 2. Efficiency of membrane transmission by aphids of purified pepper isolates of potato virus $\mathrm{Y}$ (PVY) pathotypes $1-2$ and 0 in the presence of homologous or heterologous helper components $(\mathrm{HC})^{\mathrm{a}}$

\begin{tabular}{|c|c|c|c|c|c|c|c|}
\hline \multirow[b]{2}{*}{ Source of HC } & \multirow[b]{2}{*}{ HC dilution } & \multicolumn{3}{|c|}{ PVY 1-2 transmission } & \multicolumn{3}{|c|}{ PVY 0 transmission } \\
\hline & & Frequency & $\%$ & Range (\%) & Frequency & $\%$ & Range (\%) \\
\hline \multirow[t]{2}{*}{ PVY 1-2 } & $1: 2$ & $7 / 50$ & 14 & $0-27$ & $6 / 70$ & 9 & $0-20$ \\
\hline & $1: 5$ & $6 / 70$ & 9 & $0-7$ & $2 / 53$ & 4 & $0-7$ \\
\hline \multirow[t]{3}{*}{ PVY 0 AT } & $1: 2$ & $25 / 27$ & 93 & $84-100$ & $28 / 30$ & 94 & $87-100$ \\
\hline & $1: 5$ & $24 / 27$ & 89 & $87-92$ & $\ldots \mathrm{b}$ & $\ldots$ & $\ldots$ \\
\hline & $1: 10$ & $24 / 30$ & 80 & $74-87$ & $\ldots$ & $\ldots$ & $\ldots$ \\
\hline
\end{tabular}

${ }^{a}$ Aphids (Myzus persicae) were starved for 2 to $3 \mathrm{~h}$ and allowed to feed for 5 to $10 \mathrm{~min}$ through stretched Parafilm membranes on a solution containing purified virions $(50 \mu \mathrm{g} / \mathrm{ml})$ mixed with partially purified $\mathrm{HC}$ in $0.1 \mathrm{M}$ Tris- $\mathrm{H}_{2} \mathrm{SO}_{4}, \mathrm{pH} 7.2,20 \mathrm{mM} \mathrm{MgSO}_{4}$, and $20 \%$ sucrose. A total of 10 aphids per assay plant was used. Transmission frequencies are indicated by number of infected plants/total number of tested plants and are the combined results of at least three independent experiments with two different HC preparations.

${ }^{b}$ Not performed. 
$\begin{array}{lllllllllllllllllllllllllll}S & N & A & E & N & F & W & K & G & \text { L } & D & N & N & \text { W } & \text { A } & \text { R } & \text { M } & \text { R } & \text { Y } & \text { P } & 20\end{array}$ TCA AAT GCT GAG AAT TTT TGG AAG GGT TTG GAC AAC AAC TGG GCA CGA ATG AGA TAC CCT 60

$\begin{array}{lllllllllllllllllllllllllllllllllllll}S & D & H & T & C & I & A & G & L & P & V & E & D & C & G & R & V & A & A & L & 40\end{array}$ TCA GAT CAT ACA TGT ATA GCT GGT CTA CCA GTT GAG GAC TGC GGT AGG GTC GCT GCA TTG 120

$\begin{array}{llllllllllllllllllllll}M & \mathrm{~T} & \mathrm{H} & \mathrm{S} & \mathrm{I} & \mathrm{L} & \mathrm{P} & \mathrm{C} & \mathrm{Y} & \mathrm{K} & \mathrm{M} & \mathrm{T} & \mathrm{C} & \mathrm{P} & \mathrm{T} & \mathrm{C} & \mathrm{A} & \mathrm{Q} & \mathrm{Q} & \mathrm{Y} & 60\end{array}$ ATG ACA CAC AGC ATT TTG CCA TGT TAC AAG ATG ACC TGC CCC ACC TGT GCT CAA CAA TAT 180

$\begin{array}{llllllllllllllllllllll}\text { A } & \mathbb{N} & \mathrm{L} & \mathrm{P} & \mathrm{T} & \mathrm{S} & \mathrm{D} & \mathrm{L} & \mathrm{F} & \mathrm{K} & \mathrm{L} & \mathrm{L} & \mathrm{H} & \mathrm{K} & \mathrm{H} & \mathrm{A} & \mathrm{R} & \mathrm{D} & \mathrm{G} & \mathrm{L} & 80\end{array}$ GCE AAC TTG CCA ACC AGT GAT TTG TTC AAg CTG TTG CAㅡ AAA CAT GCA AGg GAC GGT TTG 240

$\begin{array}{lllllllllllllllllllllll}S & R & L & G & S & D & K & D & Q & F & V & H & V & S & K & F & L & E & T & L & 100\end{array}$ AGT CGA TTG GGA TCA GAT AAA GAT CAA CTC GTG CAT GTT AGT AAG. TTC TTG GAA ACG TTG 300

$\begin{array}{llllllllllllllllllllll}\mathrm{E} & \mathrm{H} & \mathrm{L} & \mathrm{T} & \mathrm{E} & \mathrm{P} & \mathrm{V} & \mathrm{D} & \mathrm{L} & \mathrm{N} & \mathrm{L} & \mathrm{E} & \mathrm{L} & \mathrm{F} & \mathrm{N} & \mathrm{E} & \mathrm{I} & \mathrm{F} & \mathrm{K} & \mathrm{S} & 120\end{array}$ GAG CAT TTA ACT GAA CCA GTT GAC TTA AAT CTC GAG CTT TT $\underline{\underline{T}}$ AAT GAG ATA TTC AAA TCC 360

$\begin{array}{llllllllllllllllllllll}I & G & E & K & Q & Q & A & P & F & K & N & L & N & V & L & N & N & F & F & L & 140\end{array}$ ATA GGG GAG AAG CAG CAA GCA CCA TTC AAG AAT TTG AAT GTC TTA AAC AAC TTC TTT TTG 420

$\begin{array}{llllllllllllllllllllll}K & G & K & E & N & T & A & H & E & W & Q & I & A & Q & L & S & L & L & E & L & 160\end{array}$ AAA GGA AAA GAA AAT ACA GCT CAT GAA TGG CAG ATA GCT CAA TTG AGT TTG CTC GAA TTA 480

$\begin{array}{lllllllllllllllllllll}S & R & F & Q & K & N & R & T & D & N & I & K & K & G & D & I & S & F & F & R & 180\end{array}$ TCA AGA TTC CAG AAg AAT AGA ACT GAT AAT ATA AAg AAA GGT GAC ATA TCT TTC TTC AGG 540

$\begin{array}{lllllllllllllllllllll}\mathrm{N} & \mathrm{K} & \mathrm{L} & \mathrm{S} & \mathrm{A} & \mathrm{K} & \mathrm{A} & \mathrm{N} & \mathrm{W} & \mathrm{N} & \mathrm{L} & \mathrm{Y} & \mathrm{L} & \mathrm{S} & \mathrm{C} & \mathrm{D} & \mathrm{N} & \mathrm{Q} & \mathrm{L} & \mathrm{D} & 200\end{array}$ AAC AAA TTG TCA GCC AAA GCA AAC TGG AAT CTTG TAT TTA TCG TGC GAC AAT CAG TTG GAT 600

$\begin{array}{llllllllllllllllllllll}K & \mathrm{~N} & \mathrm{~A} & \mathrm{~N} & \mathrm{~F} & \mathrm{~L} & \mathrm{~W} & \mathrm{G} & \mathrm{Q} & \mathrm{R} & \mathrm{E} & \mathrm{Y} & \mathrm{H} & \mathrm{A} & \mathrm{K} & \mathrm{R} & \mathrm{F} & \mathrm{F} & \mathrm{S} & \mathrm{N} & 220\end{array}$ AAA AAT GCA AAC TTC CTG TGG GGA CAA AGG GAG TAT CAT GCT AAG CGG TTT TTC TCA AAC 660

$\begin{array}{llllllllllllllllllllll}F & F & E & E & V & D & P & T & K & G & Y & S & A & Y & E & I & R & K & H & P & 240\end{array}$ TTC TTT GAG GAA GTT GAT CCA ACA AAG GGA TAC TCA GCA TAT GAA ATC CGC AAg CAT CCG 720

$\begin{array}{llllllllllllllllllllll}\mathrm{N} & \mathrm{G} & \mathrm{T} & \mathrm{R} & \mathrm{K} & \mathrm{L} & \mathrm{S} & \mathrm{I} & \mathrm{G} & \mathrm{N} & \mathrm{L} & \mathrm{V} & \mathrm{V} & \mathrm{P} & \mathrm{L} & \mathrm{D} & \mathrm{L} & \mathrm{A} & \mathrm{E} & \mathrm{F} & 260\end{array}$ AAT GGA ACA AGG AAG CTC TCA ATT GGT AAC TTA GTT GTC CCA CTT GAT TTA GCT GAA TTT 780

$\begin{array}{lllllllllllllllllllllllll}R & Q & R & M & K & G & D & Y & R & K & Q & P & G & V & S & K & K & C & T & S & 280\end{array}$ AGA CAG AGG ATG AAA GGT GAC TAT AGG AAA CAA CCA GGG GTC AGC AAA AAG TGC ACA AGT 840

$\begin{array}{llllllllllllllllllllll}S & K & D & G & N & Y & V & Y & P & C & C & C & T & T & \text { L } & D & D & G & S & A & 300\end{array}$ TCG AAA GAT GGT AAT TAT GTA TAT CCT TGT TGE TGC ACA ACA CTT GAT GAT GGT TCA GCC 900

$\begin{array}{llllllllllllllllllllllllllll}I & E & S & T & F & Y & P & P & T & K & K & H & \text { L } & \text { V } & \text { I } & G & \text { N } & S & G & D & 320\end{array}$ ATT GAA TCA ACA TTC TAT CCG CCA ACT AAA AAG CAT CTT GTA ATA GGC AAT AGT GGT GAC 960

$\begin{array}{llllllllllllllllllllllllllllll}Q & K & Y & V & D & I & P & K & G & D & S & E & M & L & Y & I & A & K & Q & G & 340\end{array}$ CAG AAA TAT GTT GAT TTA CCA AAA GGT GAT TCG GAG ATG TTG TAC ATC GCC AAG CAA GGT 1020

$\begin{array}{lllllllllllllllllllllll}\mathrm{Y} & \mathrm{C} & \mathrm{Y} & \mathrm{I} & \mathrm{N} & \mathrm{V} & \mathrm{F} & \mathrm{I} & \mathrm{A} & \mathrm{M} & \mathrm{L} & \mathrm{I} & \mathrm{N} & \mathrm{V} & \mathrm{S} & \mathrm{E} & \mathrm{E} & \mathrm{D} & \mathrm{A} & \mathrm{K} & 360\end{array}$ TAC TGC TAT ATC AAC GTG TTT CTT GCA ATG CTA ATT AAC GTT AGC GAG GAG GAC GCA AAG 1080 $\begin{array}{lllllllllllllllllllllllllll}D & \mathrm{~F} & \mathrm{~T} & \mathrm{~K} & \mathrm{~K} & \mathrm{~V} & \mathrm{R} & \mathrm{D} & \mathrm{M} & \mathrm{C} & \mathrm{V} & \mathrm{P} & \mathrm{K} & \mathrm{L} & \mathrm{G} & \mathrm{T} & \mathrm{W} & \mathrm{P} & \mathrm{T} & \mathrm{M} & 380\end{array}$ GAT TTC ACA AAG AAA GTT CGT GAC ATG TGT GTG CCA AAG CTT GGA ACC TGG CCA ACT ATG 1140

$\begin{array}{llllllllllllllllllllll}M & \mathrm{D} & \mathrm{L} & \mathrm{A} & \mathrm{T} & \mathrm{T} & \mathrm{C} & \mathrm{A} & \mathrm{Q} & \mathrm{M} & \mathrm{R} & \mathrm{I} & \mathrm{F} & \mathrm{Y} & \mathrm{P} & \mathrm{D} & \mathrm{V} & \mathrm{H} & \mathrm{D} & \mathrm{A} & 400\end{array}$ ATG GAT TTG GCG ACT ACT TGT GCT CAA ATG AGA ATA TTC TAC CCT GAC GTG CAC GAT GCG 1200

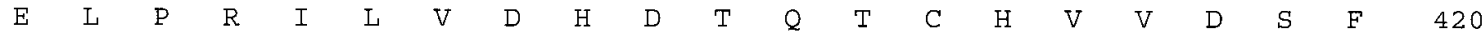
GAA TTG CCC AGA ATA TTA GT $\underline{\underline{T}}$ GAC CAT GAT ACT CAG ACG TGT CAC GTG GTT GAC TCT TTT 1260 $\begin{array}{lllllllllllllllllllll}G & S & Q & T & T & G & Y & H & I & L & K & A & S & S & V & S & Q & L & I & L & 440\end{array}$ GGT TCG CAA ACA ACT GGG TAC CAT ATT CTA AAA GCA TCT AGT GTG TCT CAA CTC ATC TTG 1320 $\begin{array}{ccccccccccccccccr}\text { F } & \text { A } & \text { N } & \text { D } & \text { E } & \text { L } & \text { E } & \text { S } & \text { D } & \text { I } & \text { K } & \text { H } & \text { Y } & \text { R } & \text { V } & \text { G } & 456 \\ \text { TTT } & \text { GCA } & \text { AAT } & \text { GAT } & \text { GAG } & \text { TTA } & \text { GAA } & \text { TCT } & \text { GAT } & \text { ATA } & \text { AAA } & \text { CAC } & \text { TAT } & \text { AGA } & \text { GTT } & \text { GGT } & 1368\end{array}$

Fig. 2. Nucleotide sequence of the helper component (HC) gene of pepper isolate pathotype 1-2 of potato virus Y (PVY) and its deduced amino acid sequence. Nucleotide differences between PVY 1-2 and PVY 0 AT HCs are underlined on the PVY 1-2 sequence. Amino acid differences are boxed. Numbers to the right show the position from the $\mathrm{N}$ terminus of the $\mathrm{HC}$. 
as judged by western blot analysis (data not shown). Unexpectedly, in vitro membrane transmission of either PVY 1-2 or PVY 0 virions complemented with PVY 1-2 HC was successful, but with low efficiency (Table 2). Therefore, the PVY 1-2 HC seemed to be ineffective in promoting high rates of transmission of either of these isolates when tested at a series of dilutions in membraneacquisition experiments (Table 2). In contrast, PVY 0 AT HC was able to assist the transmission of PVY 1-2 and PVY 0 AT at high rates (Table 2), indicating that PVY 1-2 virions can be efficiently transmitted when supplemented with an active HC, thus suggesting that a defect in the $\mathrm{HC}$ protein, rather than in the $\mathrm{CP}$, of the PVY 1-2 might cause this deficiency in the virus transmission. On the other hand, no infection was shown in membrane aphid transmission experiments performed with partially purified $\mathrm{HC}$ alone, ruling out virus contamination.

Additionally, the lack of transmission of PVY 1-2 from plants apparently cannot be attributed to a low titer of virus or $\mathrm{HC}$ in the plant because the amounts of viral $\mathrm{CP}$ and $\mathrm{HC}$ as determined by SDS-PAGE and western blot, respectively, from purified preparations were as high as those from PVY 0 AT (data not shown).

Binding of PVY 1-2 virions to HCs. In vitro binding assays were performed to elucidate whether the low efficiency of aphid transmissibility of PVY 1-2 was due to inability of virions to interact with HC. PVY 1-2 virions were able to consistently bind to HC proteins from PVY 1-2, PVY 0 AT, and TEV that were dot blotted onto nitrocellulose membranes following the protocol of Blanc et al. (6; Fig. 1). The weak positive reactions recorded in the buffer-incubated membranes were due to low traces of contaminating CPs in the PVY HC preparations.

Sequence analysis of the PVY 1-2 HC. The CP of PVY 1-2 was functional in aphid transmission but its $\mathrm{HC}$ was unable to transmit efficiently either PVY 1-2 or PVY 0 AT in membrane acquisition experiments; therefore, we determined the nucleotide sequence of the PVY 1-2 HC gene (Fig. 2) and compared it with that of PVY 0 AT, already published (8), to find out which amino acid changes,

A

$\begin{array}{ll}\text { PVY } & 1-2 \\ \text { PVY } & 1 \\ \text { PVY } & \text { AT } \\ \text { PVC } & \\ \text { PVY N } \\ \text { PVY H } \\ \text { TVMV } \\ \text { TEV } \\ \text { PPV } \\ \text { TUMV }\end{array}$

B

PVY $1-2$
PVY 1
PVY 0 AT
PVC
PVY N
PVY H
TVMV
TEV
PPV
TUMV

145

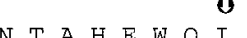

WO I A I I L L E IS R F

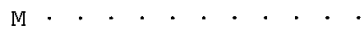

$\mathrm{M} \cdot \cdot \cdot \cdot \cdot \cdot \cdot \cdot \cdot \cdot \cdot \cdot$

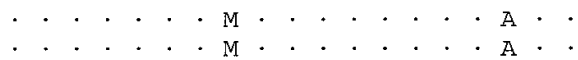

$\cdot \cdot \cdot \cdot \cdot \cdot \cdot \mathrm{M} \cdot \cdot \cdot \cdot \cdot \cdot \cdot \cdot \cdot \mathrm{C} \cdot \mathrm{A} \cdot$

$A N P D S L A K \cdot S D \cdot$. . . A $~ \cdot Y$

$L \cdot G A D L E E \cdot S T H M \cdot$. I A .

$M S \cdot Q D Y I E \cdot S D H \cdot R \cdot A \cdot A$

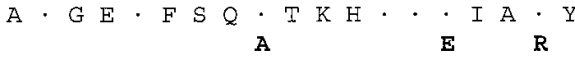

Fig. 3. Alignment of two regions of helper component sequence of six potato virus Y (PVY) isolates and potyviruses tobacco vein mottle virus (TVMV), tobacco etch virus (TEV), plum pox virus (PPV), and turnip mosaic virus (TuMV). Arrows indicate the amino acid changes found between PVY 1-2 and PVY 0 AT. Amino acid differences are indicated below the PVY 1-2 sequence. Dots indicate the same residues are present. Conserved amino acids are shown in bold below the alignment. A, Alignment of amino acids 82 to 100. B, Alignment of amino acids 145 to 163 . if any, might lead to a partial loss of activity of the PVY 1-2 HC during the transmission process. The deduced amino acid sequences also were compared with those of other strains of PVY and other potyviruses (Figs. 3 and 4).

Of the 19 nucleotide sequence differences found between the HC of PVY 0 AT and PVY 1-2, 17 did not involve amino acid changes; the remaining 2 changes induced amino acid substitutions (Fig. 2), indicating that either of these amino acid changes, or both, might be candidates involved in the lack of plant-to-plant transmission and the great reduction of in vitro aphid transmission of PVY 1-2. The first, a G to A change at nucleotide position 266, led to an Arg (PVY 0 AT) to Gln (PVY 1-2) change at amino acid position 89; and the second, a $\mathrm{G}$ to $\mathrm{A}$ mutation at nucleotide position 456, replaced a Met (PVY 0 AT) with Ile (PVY 1-2) at amino acid position 152 (Fig. 2). Interestingly, neither of these two PVY 1-2-specific amino acid changes at positions 89 and 152 occurred in the conserved $\mathrm{HC}$ domains involved in aphid transmission (KITC and PTK), which are present in most known potyviruses (Fig. 4). However, these two amino acids are highly conserved among PVY strains (Fig. 3). As reported for the transmissible PVY 0 AT (8), the amino acid sequence of PVY 1-2 HC has a KMTC motif instead of the highly conserved KITC motif. This motif, as well as the PTK motif, is suggested to be involved in aphid- and CPbinding, respectively $(5,21)$.

\section{DISCUSSION}

A PVY isolate belonging to the pepper pathotype 1-2 was characterized as non-aphid transmissible in plant-to-plant transmission tests. Its loss of transmissibility may presumably be the result of successive mechanical inoculations by which mutations deleterious to aphid transmission could be incorporated into the virus genome, as has been found for other potyviruses $(15,16,27)$. However, high rates of virus transmission of this isolate could be achieved if aphids were allowed to acquire biologically active HC prior to the virions in membrane tests. This indicated that viral $\mathrm{CP}$ was functionally active for transmission and suggested that a deficiency in $\mathrm{HC}$ was responsible for the efficiency of virus transmis-
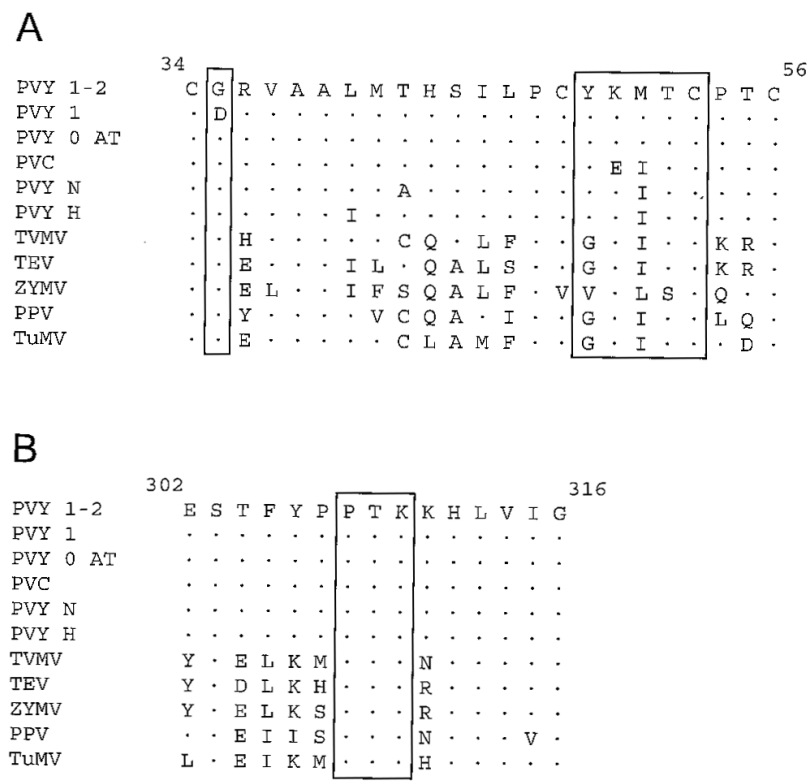

Fig. 4. Alignment of two helper component regions containing highly conserved domains involved in aphid transmission of potato virus Y (PVY) isolates and potyviruses tobacco vein mottle virus (TVMV), tobacco etch virus (TEV), zucchini yellow mosaic virus (ZYMV), plum pox virus (PPV), and turnip mosaic virus (TuMV). Amino acid differences are indicated below the PVY 1-2 HC sequence. Dots indicate the same residues are present. Amino acids required for aphid transmission are boxed. A, Alignment of amino acids 34 to 56. B, Alignment of amino acids 302 to 316 . 
sibility. Surprisingly, PVY 1-2 HC preparations assisted low levels of aphid transmission of purified virions from PVY 0 and PVY 1-2 isolates. It is not clear why PVY 1-2 was weakly transmissible when aphids acquired purified virions mixed with PVY 1-2 HC through membrane, but was non-aphid transmissible in plant-toplant assays. This phenomenon may be due to the presence of a higher concentration of $\mathrm{HC}$, virions, or putative host factors associated with $\mathrm{HC}$ in the artificial feeding solution, as has recently been proposed (11).

Amino acid sequence analysis of the PVY 1-2 HC protein revealed two amino acid changes with respect to that of the aphidtransmissible PVY 0 AT (Gln to Arg, at position 89, and Ile to Met, at position 152) that affect amino acid residues highly conserved among PVY strains. Such mutations could be somehow involved in the aphid-transmission efficiency of PVY 1-2 by altering either the dimerization of the $\mathrm{HC}$ monomer $(3,29)$ or the folding of the $\mathrm{HC}$ protein, masking any of the motifs required for $\mathrm{HC}$-virion or $\mathrm{HC}$ stylet interactions. However, we have shown that neither of the mutations found in the PVY 1-2 HC had a negative effect on its ability to bind virions; therefore, a plausible explanation for the loss of $\mathrm{HC}$ function is that either of these mutations, or both, render the HC incapable of interacting with the stylets. On the other hand, PVY 1-2 HC mutations might affect the stability of the protein in the host cell and, therefore, reduce the amount of available biologically active $\mathrm{HC}$ in the infected tissue in such a way that it is not sufficient to promote aphid transmission from plants.

It is important to note that the substitution of the basic Arg for the uncharged Gln at position 89 in the PVY 1-2 HC amino acids sequence lies in position -1 with respect to a conserved Phe (Fig. 3 ), suggesting that this change of charge might affect the ability of PVY 1-2 HC to mediate aphid transmission. In fact, a number of examples of loss of aphid transmission due to changes in the charge or polarity of a single amino acid in conserved domains of the $\mathrm{HC}$ sequence of potyviruses have been reported. A Lys to Glu change in the highly conserved KITC motif of the HC of TVMV (4), TEV (5), and potato virus C (PVC; 30) resulted in loss of HC activity. A substitution of Lys to Asn in the KMTC motif of PVY 0 (8) and Lys to Glu in the KLSC motif of ZYMV (13) have similar phenotypic effects. The presence of a positively charged amino acid at the first position of these conserved motifs, therefore seems to be essential for HC activity (4). Other mutations leading to charge changes in different regions of the $\mathrm{HC}$ adversely affecting $\mathrm{HC}$ activity have also been described. These include a Gly to Asp at position 35 of PVY 1 HC (8) and a Gly to Glu preceding the KITC sequence in TuMV (20).

The second amino acid replacement found in the PVY 1-2 HC at position 152 also occurred in position -1 with respect to a conserved Ala (Fig. 3). However, this mutation did not cause a charge change because both residues are hydrophobic nonpolar amino acids. Nevertheless, it would be not surprising if this change of Met to Ile were detrimental to aphid transmissibility of the PVY $1-2$, because substitutions between amino acids with similar characteristics have been proved to abolish aphid transmission. Replacing Lys by His in the KITC motif of TVMV (4) resulted in loss of $\mathrm{HC}$ activity.

The mentioned mutations in highly conserved regions at the $\mathrm{N}$ terminus of the HC sequence of potyviruses are located within or near the cysteine-rich domain. Such motifs have been reported to form tertiary structures having functional roles and also may bind metal ions that could be required for HC biological activity (3, 23,26).

Recently, the loss of aphid transmissibility of TEV has been shown to be due to a substitution of Phe to Leu (both hydrophobic nonpolar amino acids) at nonconserved amino acid 10 of the TEV HC (5). Therefore, the PVY 1-2 HC mutations, which are located in nonconserved positions outside the cysteine-rich domain, also may be associated with the inability of HC to mediate highly efficient aphid transmission of PVY 1-2. Further information about the spatial structure or folding of potyvirus $\mathrm{HC}$ is needed for a better understanding of the involvement in transmission of amino acid changes in the $\mathrm{HC}$ sequence.

\section{ACKNOWLEDGMENTS}

This work was funded by grants BIO98-0849 from CICYT and 07B0024-1997 from CAM (Spain). C. Llave and B. Martínez received fellowships from the PNFPI and INFPI (Spain), respectively. We thank T. P. Pirone for his critical review and valuable suggestions and A. Díaz, G. Porras, and S. Carbajo for assistance with DNA sequencing.

\section{LITERATURE CITED}

1. Allison, R., Johnston, R. E., and Dougherty, W. G. 1986. The nucleotide sequence of the coding region of tobacco etch virus genomic RNA: Evidence for the synthesis of a single polyprotein. Virology 154:9-20.

2. Ammar, E. D., Järlfors, U., and Pirone, T. P. 1994. Association of potyvirus helper component protein with virions and the cuticle lining the maxillary food canal and foregut of an aphid vector. Phytopathology 84:10541060.

3. Atreya, C. D., Atreya, P. L., Thornbury, D. W., and Pirone, T. P. 1992. Sitedirected mutations in the potyvirus HC-Pro gene affect helper component activity, virus accumulation, and symptom expression in infected tobacco plants. Virology 191:106-111.

4. Atreya, C. D., and Pirone, T. P. 1993. Mutational analysis of the helper component-proteinase gene of a potyvirus: Effects of amino acid substitutions, deletions, and gene replacement on virulence and aphid transmissibility. Proc. Natl. Acad. Sci. USA 90:11919-11923.

5. Blanc, S., Ammar, E. D., Garcia-Lampasona, S., Dolja, V. V., Llave, C., Baker, J., and Pirone, T. P. 1998. Mutations in the potyvirus helper component protein: Effects on interaction with virions and aphid stylets. J. Gen. Virol. 79:3119-3122.

6. Blanc, S., Dolja, V. V., Llave, C., and Pirone, T. P. 1999. Histidine-tagging and purification of tobacco etch potyvirus helper component protein. J. Virol. Methods 77:11-15.

7. Canto, T., Ellis, P., Bowler, G., and López-Abella, D. 1995. Production of monoclonal antibodies to potato virus $\mathrm{Y}$ helper component-protease and their use for strain differentiation. Plant Dis. 79:234-237.

8. Canto, T., López-Moya, J. J., Serra-Yoldi, M. T., Díaz-Ruíz, J. R., and López-Abella, D. 1995. Different helper component mutations associated with lack of aphid transmissibility in two isolates of potato virus Y. Phytopathology 85:1519-1524.

9. De Bokx, J. A., and Huttinga, H. 1981. Potato Virus Y. CMI/AAB Descr. Plant Viruses No. 242.

10. Domier, L. L., Franklin, K. M., Shahabuddin, M., Hellmann, G. M. Overmeyer, J. H., Hiremath, S. T., Siaw, M. F. E., Lomonosoff, G. P., Shaw, J. G., and Rhoads, R. E. 1986. The nucleotide sequence of tobacco vein mottling virus RNA. Nucleic Acids Res. 14:5417-5470.

11. Flasinski, S., and Cassidy, B. G. 1998. Potyvirus aphid transmission requires helper component and homologous coat protein for maximal efficiency. Arch. Virol. 143:2159-2172.

12. Gebre-Selassie, K., Marchoux, G., Delecolle, B., and Pochard, E. 1985. Variabilité naturelle des souches du virus Y de la pomme de terre dans les cultures de piment du sud-est de la France. Caracterisation et classification en pathotypes. Agronomie 5:621-630.

13. Granier, F., Durand-Tardif, M., Casse-Delbart, F., Lecoq, H., and Robaglia, C. 1993. Mutations in zucchini yellow mosaic virus helper component protein associated with loss of aphid transmissibility. J. Gen. Virol. 74: 2737-2742.

14. Lain, S., Riechmann, J. L., and García, J. A. 1989. The complete nucleotide sequence of plum pox potyvirus RNA. Virus Res. 13:157-172.

15. Lecoq, H., Bourdin, D., Raccah, B., Hiebert, E., and Purcifull, D. E. 1991. Characterization of a zucchini yellow mosaic virus isolate with deficient helper component. Phytopathology 81:1087-1091.

16. Legavre, T., Maia, I. G., Casse-Delbart, F., and Bernardi, F. 1996. Switches in the mode of transmission select for or against a poorly aphid-transmissible strain of potato virus $\mathrm{Y}$ with reduced helper component and virus accumulation. J. Gen. Virol. 77:1343-1347.

17. Matthews, R. E. F. 1991. Plant Virology. Academic Press, San Diego, CA.

18. Murphy, F. A., Fauquet, C. M., Bishop, D. H. L., Gabrial, S. A., Jarvis, A. W., Martelli, G. P., Mayo, M. A., and Summers, M. D. 1995. Virus Taxonomy. 6th Rep. Int. Comm. Taxon. Viruses. Springer-Verlag, New York.

19. Murphy, J. F., Rhoads, R. E., Hunt, A. G., and Shaw, J. G. 1990. The VPg of tobacco etch virus RNA is the 49-kDa proteinase of the N-terminal 24-kDa part of the proteinase. Virology 178:285-288.

20. Nakashima, H., Sako, N., and Hori, K. 1993. Nucleotide sequences of the helper component-proteinase genes of aphid transmissible and non- 
transmissible isolates of turnip mosaic virus. Arch. Virol. 131:7-27.

21. Peng, Y., Kadoury, D., Gal-On, A., Huet, H., Wang, Y., and Raccah, B. 1998. Mutations in the HC-Pro gene of zucchini yellow mosaic potyvirus: Effects on aphid transmission and binding to purified virions. J. Gen. Virol. 79:897-904.

22. Pirone, T. P. 1981. Efficiency and selectivity of the helper-component-mediated aphid transmission of purified Potyvirus. Phytopathology 71:922-924.

23. Pirone, T. P., and Blanc, S. 1996. Helper-dependent vector transmission of plant viruses. Annu. Rev. Phytopathol. 34:227-247.

24. Pirone, T. P., and Thornbury, D. W. 1983. Role of virion and helper component in regulating aphid transmission of tobacco etch virus. Phytopathology 73:872-875.

25. Quemada, H., Sieu, L.C., Siemieniak, D. R. Gosalves, D., and Slightom, J. L. 1990. Watermelon mosaic virus II and zucchini yellow mosaic virus: Cloning of 3 'terminal regions, nucleotide sequences, and phylogenetic comparisons. J. Gen. Virol. 71:1451-1460

26. Robaglia, C., Durand-Tardif, M., Trochet, M., Boudazin, G., AstierManifacier, S., and Casse-Delbart, F. 1989. Nucleotide sequence of potato virus Y (N strain) genomic RNA. J. Gen. Virol. 70:935-947.

27. Sako, N. 1980. Loss of aphid-transmissibility of turnip mosaic virus. Phytopathology 70:647-649.

28. Thompsom, J. D., Higgins D. G., and Gibson T. J. 1994. CLUSTAL W:
Improving the sensitivity of progressive multiple sequence alignment though sequence weighting, position-specific gap penalties and weight matrix choice. Nucleic Acids Res. 22:4673-4680.

29. Thornbury, D. W., Hellmann, C. A., Rhoads, R. E., and Pirone, T. P. 1985. Purification and characterization of potyvirus helper component. Virology 144:260-267.

30. Thornbury, D. W., Patterson, C. A., Dessens, J. T., and Pirone, T. P. 1990. Comparative sequence of the helper component $(\mathrm{HC})$ region of potato virus $\mathrm{Y}$ and a HC-defective strain, potato virus C. Virology 178:573-578.

31. Towbin, H., Staehlin, T., and Gordon, J. 1979. Electrophoretic transfer of protein from polyacrylamide gels to nitrocellulose sheets: Procedure and some applications. Proc. Natl. Acad. Sci. USA 76:4350-4354.

32. Tremblay, M. F., Nicolas, O., Sinha, R. C. M., Lazure, C., and Laliberté, J. F. 1990. Sequence of the 3'-terminal region of turnip mosaic virus RNA and the capsid protein gene. J. Gen. Virol. 71:2769-2772.

33. Wang, R. Y., Ammar, E. D., Thornbury, D. W., López-Moya, J. J., and Pirone, T. P. 1996. Loss of potyvirus transmissibility and helper-component activity correlate with non-retention of virions in aphid stylets. J. Gen. Virol. 77:861-867.

34. Wetzel, T., Candresse, T., Macquaire G., Ravelonandro, M., and Dunez, J. 1992. A highly sensitive immunocapture polymerase chain reaction method for plum pox potyvirus. J. Virol. Methods 39:27-37. 